\title{
THERMAL MODIFICATION OF Eucalyptus grandis WOOD: VARIATION OF COLORIMETRIC PARAMETERS
}

\author{
Pedro Henrique Gonzalez de Cademartori ${ }^{1, \star}$, Eduardo Schneid², \\ Darci Alberto Gatto ${ }^{3}$, Diego Martins Stangerlin ${ }^{4}$, Rafael Beltrame ${ }^{3}$
}

\begin{abstract}
The color modifications in Eucalyptus grandis thermally modified wood were investigated. One hundred eighty specimens $(10 \times 10 \times 200 \mathrm{~mm})$ were prepared and thermally modified in an electric kiln for 4 and $8 \mathrm{~h}$ at $180-240^{\circ} \mathrm{C}$. The color parameters $\left(L^{*}, a^{*}, \mathrm{~b}^{*}, C^{*}, h^{*}\right.$ and $\Delta E$ ) were determined by the CIE- $L * a * b *$ method on radial and tangential sections of untreated and treated wood. The results indicated the darkening of specimens in the radial and tangential sections. Both sections showed variation of $L^{*}$ between 73 and 30, $a^{*}$ between 9 and 5 and $b^{*}$ between 20 and 8 . The thermally modified wood at 180 and $200^{\circ} \mathrm{C}$ showed similar patterns, equally at 220 and $240^{\circ} \mathrm{C}$. The time of exposure indicated significance just in treatment at $200^{\circ} \mathrm{C}$.
\end{abstract}

Keywords: Heat treatment, wood modification, colorimetry, heartwood.

\section{INTRODUCTION}

Wood is a natural and heterogeneous polymer with an increasing number of non-structural and structural uses due to the fact that its technological properties can be modified. These modifications are possible through methods developed through of years, like acetylation and thermal modification.

Specifically, thermal modification is a process, which exposes wood to temperatures between 180 and $260^{\circ} \mathrm{C}$ (Hill, 2006). Thermal modifications with the use of methods like Plato-Process (Holland), Rectification Process and Bois Perdure (France), OHT Process (Germany) and Thermo Wood Process (Finland) are widely used in European industries. These methods expose wood to temperatures between 160 and $260^{\circ} \mathrm{C}$ to increase both dimensional stability and resistance to decay.

Despite the aforementioned benefits, thermal modification can cause many technological alterations in physical, mechanical and chemical wood properties. One example is color, which is characterized as a physical property and, in general, becomes darker in thermally modified wood. This modification can be explained by the formation of products resulting from the degradation of hemicelluloses (SehlstedtPersson 2003, Sundqvist 2004) and of others components such as extractives (McDonald et al. 1997). The oxidation of products like quinones also contributes for color modifications in wood (Tjeerdsma et al. 1998, Mitsui et al. 2001, Bekhta and Niemz 2003).

Moreover, the characteristics of the method such as the atmosphere of treatment, initial moisture content of wood pieces and the equipment used (closed or open system, for example) are very important because they can directly affect the properties of wood (Hill 2006, Yildiz et al. 2006).

${ }^{1}$ College of Materials Engineering, Technology Development Center (CDTec), Federal University of Pelotas, Brazil.

${ }^{2}$ College of Forest Engineering, Department of Forest Science, Rural Science Center, Federal University of Santa Maria, Brazil. eduardoschneid87@gmail.com

${ }^{3}$ College of Wood Industrial Engineering, Engineering Center, Federal University of Pelotas, Brazil. darcigatto@yahoo.com; browbeltrame@yahoo.com.br

Institute of Agricultural and Environmental Sciences, Federal University of Mato Grosso, Brazil. diego_stangerlin@yahoo.com.br Corresponding author: ^pedrocademartori@gmail.com

Received: 15.03. 2012 Accepted: 07.08. 2012. 
Bekhta and Niemz (2003) reported that when wood is thermally modified at $200^{\circ} \mathrm{C}$, color modification is more intense, with most of the darkening happening in first four hours of treatment. On the other hand, Patzelt et al. (2003) observed that color modifications of wood heated at high temperatures for short periods are not different from the ones caused by low temperatures for long periods. Anyway, wood color is modified after thermal rectification and this characteristic can determine the use of the wood. For example, timber with low commercial value can look like tropical wood - which has high commercial value - when thermally modified. Therefore, establishing wood color in an efficient way is necessary, since color is an important parameter to establish the quality of wood products. According to Abrahão (2005), homogeneity in the color of wood used in industries is necessary because it will affect the result of its final products.

CIE- $L * a * b *$ system is an efficient method to determine wood color with the use of colorimeters or spectrophotometers equipment. This method follows CIE (Commission International de L'Éclairage) regulations and can measure lightness $\left(L^{*}\right)$, chromaticity coordinates $\left(a^{*}\right.$ and $\left.b^{*}\right)$, chroma $\left(C^{*}\right)$ and hue angle $(h *)$ (Konica Minolta 2007).

Taking these facts into account, the aim of this study is to evaluate the effect of temperature and time on the color of Eucalyptus grandis thermally modified wood.

\section{MATERIAL AND METHODS}

\section{Test specimens}

Sixteen Eucalyptus grandis trees (17 years old) from homogeneous population were randomly harvested on the north coast of Rio Grande do Sul state, in the south of Brazil (30 $144^{\prime} 09.73^{\prime \prime}$, $\left.50^{\circ} 19^{\prime} 55.07^{\prime \prime} \mathrm{O}\right)$.

The first $\log$ ( $3.15 \mathrm{~m}$ length) of each tree was cut. Then, 180 specimens measuring $10 \mathrm{~mm} \times 10$ $\mathrm{mm} \times 200 \mathrm{~mm}$ (radial x tangential x longitudinal) with good orientation, made only of heartwood and absence of defects were prepared.

\section{Thermal modification}

The specimens were then placed in a climate chamber $\left(20^{\circ} \mathrm{C}\right.$ and $\left.65 \% \mathrm{RH}\right)$ to stabilize the moisture content at $12 \%$.

After the moisture content was stabilized at $12 \%$, the specimens were thermally modified in an electric kiln without forced air circulation and in low presence of oxygen. The specimens were treated at 180 , 200,220 and $240^{\circ} \mathrm{C}$ for 4 and $8 \mathrm{~h}$, and one treatment was the reference (untreated). Ten replicates were used for each treatment condition regarding time and temperature. After the treatments, the specimens were then placed in climate chamber $\left(20^{\circ} \mathrm{C}\right.$ and $\left.65 \% \mathrm{RH}\right)$ until the colorimetric evaluation.

\section{Colorimetric Evaluation}

The colorimetric evaluation was performed with a colorimeter (Konica Minolta CR-400) available at Federal University of Pelotas (Brazil). The equipment was set for D65 light source and $10^{\circ}$ of observation angle (CIE-Lab standard)

Five measurements of each specimen were taken in both radial and tangential sections, and, from that, lightness $\left(L^{*}\right)$, green-red chromatic coordinate $\left(a^{*}\right)$ and blue-yellow chromatic coordinate $\left(b^{*}\right)$ were obtained. 
The $\Delta E$ (color difference between thermal and reference treatments), $C^{*}$ (chroma) and $h^{*}$ (hue angle) were measured through Equations 1, 2 and 3.

$$
\begin{gathered}
\Delta \mathrm{E}=\left(\Delta L^{* 2}+\Delta a^{* 2}+\Delta b^{* 2}\right)^{1 / 2} \\
C^{*}=\left(a^{* 2}+b^{* 2}\right)^{1 / 2} \\
h^{*}=\operatorname{tang}^{-1}\left(b^{*} / a^{*}\right)
\end{gathered}
$$

Where: $\Delta E=$ color difference between thermal and reference treatments; $\Delta L^{*_{2}}, \Delta a^{{ }^{2}}$, $\Delta b^{* 2}=$ lightness, red-green coordinate and blue-yellow coordinate variation; $C^{*}=$ chroma; $h^{*}=$ hue angle; $a^{*}=$ red $(+)-$ green $(-)$ color coordinate; $b^{*}=$ yellow $(+)-$ blue (-) color coordinate.

\section{Statistical analysis}

The data obtained in this study were analyzed using descriptive statistics and regression analysis to establish correlation between the color parameters. Cluster analysis (agglomerative hierarchical clustering method) was used to determine the similarity among the thermal modifications. Ward's method and Euclidean distance were used for this, and the independent variables selected to group the thermal modifications were $L^{*}, a^{*}$ and $b^{*}$.

\section{RESULTS AND DISCUSSION}

Figure 1 shows the radial and tangential sections of specimens of each thermal modification.
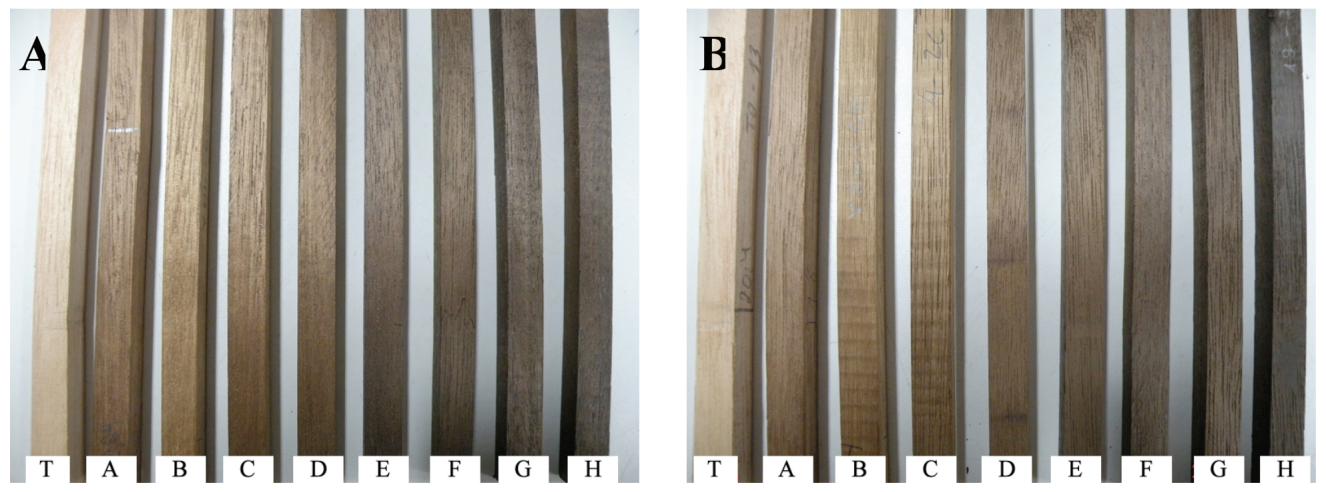

Figure 1. Color of radial (A) and tangential (B) sections of specimens of each thermal modification. $\mathrm{T}=$ without treatment; $\mathrm{A}=180^{\circ}-4 \mathrm{~h} ; \mathrm{B}=180^{\circ}-8 \mathrm{~h} ; \mathrm{C}=200^{\circ}-4 \mathrm{~h} ; \mathrm{D}=200^{\circ}-8 \mathrm{~h} ; \mathrm{E}=220^{\circ}$ $4 \mathrm{~h} ; \mathrm{F}=220^{\circ}-8 \mathrm{~h} ; \mathrm{G}=240^{\circ}-4 \mathrm{~h} ; \mathrm{H}=240^{\circ}-8 \mathrm{~h}$. 
Visual analysis of the thermally modified specimens observed gradual darkening with the increase in temperature and heating time (Figure 1). Small visual differences in color between the times of exposure to heat were also observed.

The colorimetric parameters $\left(L^{*}, a^{*}, b^{*}, C^{*}, h^{*}\right.$ and $\left.\Delta E\right)$ of $E$. grandis thermally modified wood are presented in table 1 and figure 2.

Table 1. Average values of CIELab parameters by section, temperature and time of E.grandis thermally modified wood.

\begin{tabular}{|c|c|c|c|c|c|c|c|c|}
\hline Section & $\mathrm{T}\left({ }^{\circ} \mathrm{C}\right)$ & Time (h) & $L^{*}$ & $a^{*}$ & $b^{*}$ & $C^{*}$ & $h^{*}\left({ }^{\circ}\right)$ & $\Delta E$ \\
\hline \multirow{9}{*}{ Radial } & Reference & - & $\begin{array}{l}73.25 \\
(1.62)\end{array}$ & $\begin{array}{c}9.10 \\
(0.90)\end{array}$ & $\begin{array}{l}20.53 \\
(0.73)\end{array}$ & $\begin{array}{l}22.46 \\
(1.00)\end{array}$ & $\begin{array}{l}66.15 \\
(1.50)\end{array}$ & - \\
\hline & \multirow{2}{*}{180} & 4 & $\begin{array}{l}50.98 \\
(3.59)\end{array}$ & $\begin{array}{c}9.97 \\
(0.96)\end{array}$ & $\begin{array}{l}18.17 \\
(1.01)\end{array}$ & $\begin{array}{l}20.75 \\
(0.91)\end{array}$ & $\begin{array}{l}61.24 \\
(2.94)\end{array}$ & 22,40 \\
\hline & & 8 & $\begin{array}{l}48.19 \\
(2.98)\end{array}$ & $\begin{array}{c}9.84 \\
(0.89)\end{array}$ & $\begin{array}{l}18.70 \\
(1.38)\end{array}$ & $\begin{array}{l}21.15 \\
(1.38)\end{array}$ & $\begin{array}{l}62.21 \\
(2.45)\end{array}$ & 25,13 \\
\hline & \multirow{2}{*}{200} & 4 & $\begin{array}{l}43.20 \\
(0.89)\end{array}$ & $\begin{array}{c}9.01 \\
(0.63)\end{array}$ & $\begin{array}{l}17.30 \\
(1.00)\end{array}$ & $\begin{array}{c}19.51 \\
(1.16)\end{array}$ & $\begin{array}{l}62.49 \\
(1.36)\end{array}$ & 30,22 \\
\hline & & 8 & $\begin{array}{l}37.35 \\
(2.71)\end{array}$ & $\begin{array}{c}7.76 \\
(0.48)\end{array}$ & $\begin{array}{l}13.54 \\
(1.24)\end{array}$ & $\begin{array}{l}15.61 \\
(1.20)\end{array}$ & $\begin{array}{c}60.14 \\
(1.09)\end{array}$ & 36,59 \\
\hline & \multirow{2}{*}{220} & 4 & $\begin{array}{l}35.20 \\
(1.17)\end{array}$ & $\begin{array}{c}6.88 \\
(0.41)\end{array}$ & $\begin{array}{l}12.15 \\
(1.15)\end{array}$ & $\begin{array}{c}13.96 \\
(1.14)\end{array}$ & $\begin{array}{l}60.48 \\
(1.43)\end{array}$ & 39,02 \\
\hline & & 8 & $\begin{array}{l}33.73 \\
(1.01)\end{array}$ & $\begin{array}{c}6.37 \\
(0.58)\end{array}$ & $\begin{array}{r}10.66 \\
(1.10)\end{array}$ & $\begin{array}{l}12.42 \\
(1.30)\end{array}$ & $\begin{array}{l}59.06 \\
(1.32)\end{array}$ & 40,82 \\
\hline & \multirow{2}{*}{240} & 4 & $\begin{array}{l}33.59 \\
(0.85)\end{array}$ & $\begin{array}{c}6.27 \\
(0.43)\end{array}$ & $\begin{array}{l}10.11 \\
(0.75)\end{array}$ & $\begin{array}{l}11.90 \\
(0.83)\end{array}$ & $\begin{array}{l}58.17 \\
(1.26)\end{array}$ & 41,10 \\
\hline & & 8 & $\begin{array}{l}32.33 \\
(0.97)\end{array}$ & $\begin{array}{c}5.40 \\
(0.54)\end{array}$ & $\begin{array}{c}8.50 \\
(1.33)\end{array}$ & $\begin{array}{l}10.07 \\
(1.40)\end{array}$ & $\begin{array}{l}57.35 \\
(1.88)\end{array}$ & 42,81 \\
\hline \multirow{9}{*}{ Tangential } & Reference & - & $\begin{array}{c}73.08 \\
(1.97)\end{array}$ & $\begin{array}{c}9.49 \\
(1.03)\end{array}$ & $\begin{array}{l}20.47 \\
(0.75)\end{array}$ & $\begin{array}{l}22.57 \\
(1.06)\end{array}$ & $\begin{array}{l}65.16 \\
(1.86)\end{array}$ & - \\
\hline & 180 & 4 & $\begin{array}{l}48.68 \\
(4.39)\end{array}$ & $\begin{array}{c}9.86 \\
(1.08)\end{array}$ & $\begin{array}{l}17.69 \\
(1.38)\end{array}$ & $\begin{array}{l}20.27 \\
(1.30)\end{array}$ & $\begin{array}{l}60.80 \\
(3.36)\end{array}$ & 24,56 \\
\hline & & 8 & $\begin{array}{l}46.91 \\
(2.96)\end{array}$ & $\begin{array}{c}9.60 \\
(0.71)\end{array}$ & $\begin{array}{l}18.42 \\
(1.67)\end{array}$ & $\begin{array}{l}20.79 \\
(1.58)\end{array}$ & $\begin{array}{l}62.38 \\
(2.46)\end{array}$ & 26,25 \\
\hline & \multirow[t]{2}{*}{200} & 4 & $\begin{array}{l}41.48 \\
(2.48)\end{array}$ & $\begin{array}{c}8.73 \\
(0.57)\end{array}$ & $\begin{array}{l}16.99 \\
(1.28)\end{array}$ & $\begin{array}{l}19.10 \\
(1.31)\end{array}$ & $\begin{array}{l}62.77 \\
(1.60)\end{array}$ & 31,80 \\
\hline & & 8 & $\begin{array}{l}35.24 \\
(1.67)\end{array}$ & $\begin{array}{c}7.63 \\
(0.58)\end{array}$ & $\begin{array}{l}13.35 \\
(1.50)\end{array}$ & $\begin{array}{l}15.38 \\
(1.55)\end{array}$ & $\begin{array}{l}60.20 \\
(1.50)\end{array}$ & 38,54 \\
\hline & \multirow[t]{2}{*}{220} & 4 & $\begin{array}{l}33.14 \\
(1.38)\end{array}$ & $\begin{array}{c}6.94 \\
(0.62)\end{array}$ & $\begin{array}{l}12.29 \\
(1.37)\end{array}$ & $\begin{array}{l}14.11 \\
(1.48)\end{array}$ & $\begin{array}{l}60.51 \\
(1.23)\end{array}$ & 40,85 \\
\hline & & 8 & $\begin{array}{l}31.52 \\
(1.45)\end{array}$ & $\begin{array}{c}6.26 \\
(0.72)\end{array}$ & $\begin{array}{l}10.21 \\
(1.53)\end{array}$ & $\begin{array}{c}11.98 \\
(1.65)\end{array}$ & $\begin{array}{l}58.40 \\
(1.77)\end{array}$ & 42,93 \\
\hline & \multirow[t]{2}{*}{240} & 4 & $\begin{array}{c}31.90 \\
(1.53)\end{array}$ & $\begin{array}{c}6.57 \\
(0.55)\end{array}$ & $\begin{array}{c}10.93 \\
(1.24)\end{array}$ & $\begin{array}{l}12.75 \\
(1.33)\end{array}$ & $\begin{array}{l}58.93 \\
(1.31)\end{array}$ & 42,37 \\
\hline & & 8 & $\begin{array}{l}30.48 \\
(1.48)\end{array}$ & $\begin{array}{c}5.45 \\
(0.93)\end{array}$ & $\begin{array}{c}8.71 \\
(2.04)\end{array}$ & $\begin{array}{l}10.28 \\
(2.19)\end{array}$ & $\begin{array}{l}57.68 \\
(2.84)\end{array}$ & 44,37 \\
\hline
\end{tabular}

Where: $\mathrm{T}=$ temperature $\left({ }^{\circ} \mathrm{C}\right)$; Values in parentheses corresponding to the standard deviation.

The lightness $\left(L^{*}\right)$ and color coordinates $\left(a^{*}\right.$ and $\left.b^{*}\right)$ of specimens presented a darkening tendency in radial and tangential sections. According to Ishiguri et al. (2003), the discoloration is related to the volatilization of phenolic compounds in the wood extractives. 
On the whole, the average values of $L^{*}, a^{*}$ and $b^{*}$ decreased as the temperature and heating time rose. That was also observed by Moura and Brito (2011), Esteves et al. (2008) and Unsal et al. (2003) in studies with E. grandis, E. globulus and E. camaldulensis wood respectively. According to Hill (2006), physical modifications in thermally modified wood depend heavily on the conditions of the methods applied and the colorimetric modifications are related to temperature and length of treatment.

The biggest reduction in lightness occurred in radial and tangential sections in the treatment at $240^{\circ} \mathrm{C}$ for $8 \mathrm{~h}$. Mitsui et al. (2004) reported that reduction in lightness in Cryptomeria japônica wood was ascribed to the extractives and low molecular weight compounds produced by lignin and hemicelluloses.

Furthermore, the radial section showed a smaller reduction in lightness than the tangential section. According to Burger and Richter (1991), radial section has a more shining surface due to effect of horizontal bands of rays. Nishino et al. (2000) stated that color differences between radial and tangential sections can be ascribed to anatomical characteristics like arrangement of cells, large rays and spiral grain.

The biggest reduction in the coordinate green-red $\left(a^{*}\right)$ in radial and tangential sections also occurred in the treatment at $240^{\circ} \mathrm{C}$ for $8 \mathrm{~h}$. The $a^{*}$ showed reduction since the treatment at $180^{\circ} \mathrm{C}$ for $8 \mathrm{~h}$. The constant reduction in $a^{*}$ in wood is related to the volatilization of phenolic compounds as the temperature increases (Moura and Brito 2011). The coordinate yellow-blue $\left(b^{*}\right)$ showed a similar behavior in radial and tangential sections. However, average values in radial section were higher than in the tangential section. The biggest reduction in $b^{*}$ also was at $240^{\circ} \mathrm{C}$ for $8 \mathrm{~h}$. Mori et al. (2004) observed significant influence in coordinate $b^{*}$ of Eucalyptus wood by soluble lignin levels, polyphenols and fiber length.

The chroma $\left(C^{*}\right)$ decreased with the increase in temperature and time of exposure. The average values of saturation, which identifies the purity of color in relation to white, were higher in untreated specimens (22.46 in radial and 22.57 in tangential sections) than in treated specimens - the higher the value of $C^{*}$, the closer the wood is to the original color (yellow shade).

The reduction of chroma was confirmed by the greater influence of dark gray shades in radial and tangential sections as the specimens were exposed to high temperatures. According to Camargo and Gonçalez (2001), saturation corresponds to the radius of the shade circle, from the gray point of the lightness axis to the pure spectral color (extremity of the circle).

Likewise, the hue angle $\left(h^{*}\right)$ showed a slight reduction in the average value of the reference treatment compared to the treatment at $240^{\circ} \mathrm{C}$ for $8 \mathrm{~h}(9.7 \%$ for the radial section and $5.15 \%$ for the tangential section). The $h^{*}$ of radial and tangential sections of untreated specimens presented predominantly yellow shade. On the other hand, the thermally modified specimens showed more influence of red shade. The reduction of $h^{*}$ helps to understand the darkening of wood, since its decrease allows the hue angle to approach the coordinated red-green $\left(b^{*}\right)$.

The $\Delta E$ increased as a function of the temperature, with the treatments at 220 and $240^{\circ} \mathrm{C}$ presenting the highest values of color difference. 
Figure 2 show the correlations between $L^{*}, a^{*}$ and $b^{*}$ to the radial and tangential sections of Eucalyptus grandis wood.

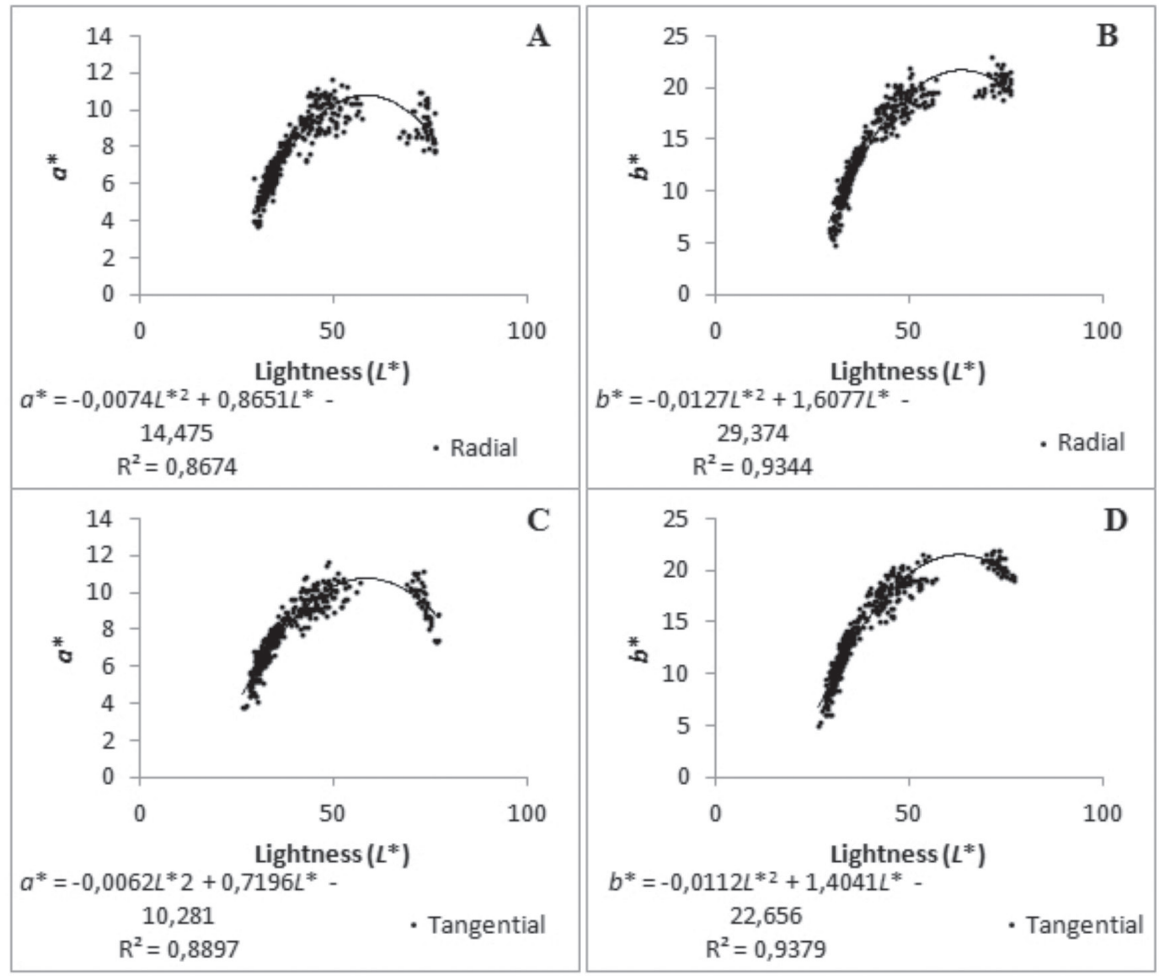

Figure 2. Correlations between $L^{*}, a^{*}$ and $b^{*}$. (A) $-L^{*}$ against $a^{*}$ in radial section; (B) $-L^{*}$ against $b^{*}$ in radial section; (C) $-L^{*} \mathrm{x} a^{*}$ in tangential section; (D) $L^{*}$ against $b^{*}$ in tangential section.

In figure 2, a significant positive correlation in radial and tangential sections for $L^{*}$ against $a^{*}$ and $b^{*}$ at $99 \%$ confidence level can be verified. Also, it shows that $b^{*}$ presented higher coefficient of determination in radial and tangential sections. Thus, it is possible to say that, in this study, color and color behavior in wood after thermal modifications are defined by a combined study of the variables $L^{*}, a^{*}$ and $b^{*}$.

Figure 3 presents the hierarchical clustering dendrograms for radial and tangential sections of Eucalyptus grandis wood. For the application of this method, each temperature and time of exposure was considered individually, totaling nine treatments.

The definition of groups was done by drawing a line parallel to the horizontal axis (Fenon Line), close to middle distance. 


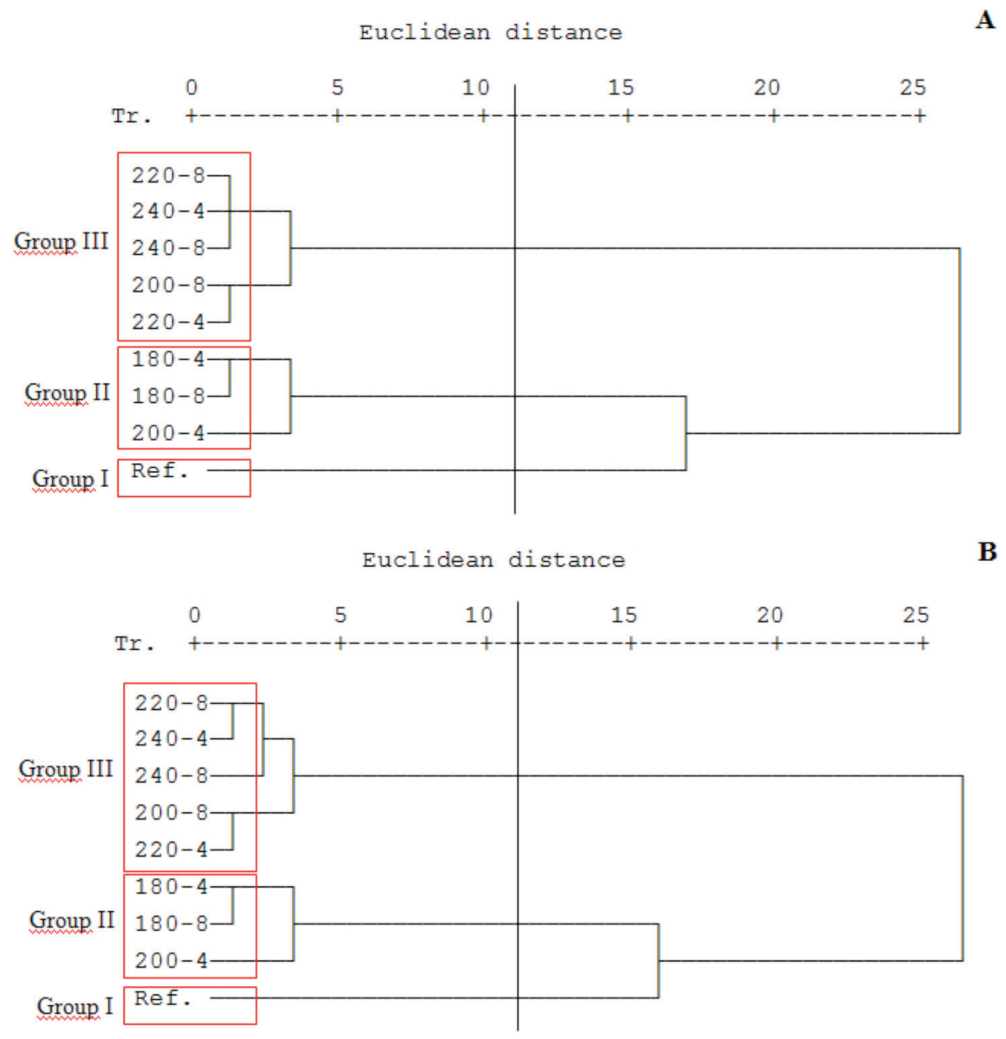

Figure 3. Dendrograms for radial (A) and tangential (B) sections of Eucalyptus grandis heat-treated wood. $\mathrm{Tr}=$ Treatment; Ref. $=$ Reference treatment (untreated specimens).

The formation of three groups for radial and tangential sections can be observed in figure 3 . The method of hierarchical clustering showed the isolation of untreated specimens (Group I) and proved the significant influence of thermal rectification on color properties of Eucalyptus grandis wood. Furthermore, Group 2 revealed similar patterns for treatments at $180^{\circ} \mathrm{C}$ for $4-8 \mathrm{~h}$ and $200^{\circ} \mathrm{C}$ for $4 \mathrm{~h}$, whereas Group 3 revealed similar patterns for treatments at $200^{\circ} \mathrm{C}$ for $8 \mathrm{~h}, 220$ and $240^{\circ} \mathrm{C}$ for $4-8 \mathrm{~h}$.

Temperature was revealed to be the variable with the most influence among the thermal modifications, since time of exposure was significant just in the treatment at $200^{\circ} \mathrm{C}$. This is shown by the fact that, at this temperature, the treatments for 4 and $8 \mathrm{~h}$ were in distinct groups.

\section{CONCLUSIONS}

The radial and tangential sections showed similar behavior within studied parameters.

However, the radial section was less susceptible to darkening than the tangential section.

The variation of lightness was better explained by $b^{*}$.

The variation in temperature was not significant between $180-200^{\circ} \mathrm{C}$ and between $220-240^{\circ} \mathrm{C}$.

The variation in time of exposure showed significance just in treatment at $200^{\circ} \mathrm{C}$. 


\section{REFERENCES}

Abrahão, C.P. 2005. Estimation for some properties of the wood of Eucalyptus urophylla by spectrometry. Ph.D. Thesis, Federal University of Viçosa, Viçosa, Brazil. 182p. (in Portuguese).

Bekhta, P; Niemz, P. 2003. Effect of high temperature on the change in colour, dimensional stability and mechanical properties of spruce wood. Holzforschung 57(5): 539-546.

Burger, M.L.; Richter, H.G. 1991. Wood anatomy. Nobel, São Paulo. Brazil. 154p (in Portuguese).

Camargos, J.A.A.; Gonçalez, J.C. 2001. The colorimetry applied as a tool in the development of a color table of wood. Brasil Florestal 20 (71):30-41 (in Portuguese).

Konica Minolta. 2007. Precise color communication: Color control from perception to instrumentation. Konica Minolta Sensing Inc., Japan.

Esteves, B.; Velez Marques, A.; Domingos, I.; Pereira, H. 2008. Heat induced colour changes of pine (Pinus pinaster) and eucalyptus (Eucalyptus globulus) wood. Wood Sci. Technol. 42 (5):369-384. UK

Hill, C.A.S. 2006. Wood modification: Chemical, thermal and other processes. John Wiley \& Sons, Chichester.

Ishiguri, F.; Maruyama, S.; Takahashi, K.; Abe, Z.; Yokota, S.; Andoh, M.; Yoshizawa, N. 2003. Extractives relating to heartwood color changes in sugi (Crytomeria japonica) by a combination of smoke-heating and UV radiation exposure. J. Wood Sci. 49 (2):135-139.

Mcdonald, A.; Fernandez, M.; Kreber, B. 1997. Chemical and UV-VIS spectroscopic study on kiln brown stain formation in Radiate pine. The $9^{\text {th }}$ International Symposium of Wood and Pulping Chemistry, Montreal, Canada. 1-5.

Mitsui, K. 2004. Changes in the properties of light-irradiated wood with heat treatment. Part 2. Effect of lightirradiation time and wavelength. Holz Roh-Werkstoff 62(1):23-30.

Mitsui, K.; Takada, H.; Sugiyama, M.; Hasegawas, R. 2001. Changes in the properties of light-irradiated wood with heat treatment: Part 1. Effect of treatment conditions on the change in colour. Holzforschung 55(6):601-605.

Mori, C.L.S.O.; Mori, F.A.; Lima, J.T.; Trugilho, P.F.; Oliveira, A.C. 2004. Influence of technological characteristics in the color of eucalypt wood. Ciência Florestal 14 (2):123-132 (in Portuguese).

Moura, L.F.; Brito, J.O. 2011. Effect of thermal rectification on colorimetric properties of Eucalyptus grandis and Pinus caribaea var. hondurensis woods. Scientia Forestalis 39 (89):69-76 (in Portuguese).

Nishino, Y.; Janin, G.; Yamada, Y.; Kitano, D. 2000. Relations between the colorimetric values and densities of sapwood. Journal of Wood Science 46(4):267-272.

Patzelt, M.; Emsenhuber, G.; Stingl, R. 2003. Colour measurement as means of quality control of thermally treated wood. The European Conference on Wood Modification, Gent, Belgium. 213-218.

Sehlstedt-Persson, M. 2003. Colour responses to heat treatment of extractives and sap from pine and spruce. The $8^{\text {th }}$ International IUFRO Wood Drying Conference, Brasov, Romania. 459-464.

Sundqvist, B. 2004. Colour changes and acid formation in wood during heating. Ph.D. Thesis, Lulea University of Technology, Lulea, Sweden. 154p.

Tjeerdsma, B.; Boonstra, M.; Pizzi, A.; Telkely, P.; Militiz, H. 1998. Characterization of thermally modified wood: molecular reasons for wood performance improvement. Holz Roh-Werkstoff 56(3):149-153.

Unsal, O.; Korkut, S.; Atik, C. 2003. The effect of heat treatments on some properties and colour in Eucalyptus camaldulensis Dehn. wood. Maderas. Ciencia y Tecnología 5 (2):145-152.

Yildiz, S.; Gezer, E. D.; Yildiz, U. C. 2006. Mechanical and chemical behavior of spruce wood modified by heat. Buildingand Environment 41(1):1762-1766 